\title{
God's fishes: religion, culture and freshwater fish conservation in India
}

\author{
Nishikant Gupta, Arun Kanagavel, Parinemta Dandekar \\ NeElesh Dahanukar, Kuppusamy Sivakumar \\ Vinod B. Mathur and Rajeev Raghavan
}

\begin{abstract}
Indigenous communities worldwide have long relied on their environment for survival. Religious and customary beliefs that foster community conservation have not only bound these communities to ecosystems but also assisted in the conservation of species. We provide an example of how religion fosters the conservation of freshwater fishes in India. Since ancient times rural communities in India have revered fish species as symbols of divine power, and offered them protection in pools associated with temples. Such voluntary, informal institutions and arrangements continue to help conserve several freshwater fish species that are otherwise subjected to anthropogenic pressure in open-access areas. However, religious beliefs in India are waning as a result of increased urbanization, modernization of societies and disintegration of rural communities, and the sustainability of existing temple and community fish sanctuaries is questionable. We discuss the role of temple sanctuaries as an informal conservation strategy for freshwater fishes, and discuss the knowledge and policy gaps that need to be addressed for ensuring their future.
\end{abstract}

Keywords Beliefs, Buddhism, fish, Hinduism, mahseer, sacred, taboos, temple sanctuaries

\section{Introduction}

$\mathrm{R}$ eligion is a powerful facilitator of the evolution of proRocial behaviour in human society (Norenzayan \& Shariff, 2008). In many countries religious beliefs have determined local resource use and facilitated the protection of

NishiKant Gupta (Corresponding author) Department of Geography, King's College London, UK. E-mail nishikantgupta@live.in

Arun Kanagavel and Rajeev Raghavan* Conservation Research Group, St. Albert's College, Kochi, India

Parineeta Dandekar South Asia Network for Dams, Rivers and People, Delhi, India

NeElesh Dahanukar Indian Institute of Science Education and Research, Pune, India

Kuppusamy Sivakumar Department of Endangered Species Management, Wildlife Institute of India, Dehradun, India

VINOD Mathur Wildlife Institute of India, Dehradun, India

*Also at: School of Fisheries Resource Management, Kerala University of Fisheries and Ocean Studies, Kochi, India

Received 24 February 2015. Revision requested 13 April 2015.

Accepted 5 May 2015. First published online 28 September 2015. species and ecosystems (Colding \& Folke, 1997; Anthwal et al., 2010), governed to an extent by the voluntary involvement of local stakeholders. Although religious adherents are distributed unequally in relation to areas important for global biodiversity, in India there is an overlap between such areas and the religions of Buddhism, Hinduism and Islam (Mikusiński et al., 2014). Circa 4 billion people in countries with biodiversity hotspots follow an organized religion, and these countries generally have low ecological footprints, with nearly $60 \%$ of people utilizing $<2$ global hectares per person (Bhagwat et al., 2011; WWF, 2014). In promoting environmental conservation this association provides an opportunity to work together that is more persuasive than the scientific importance of species (Bhagwat \& Palmer, 2009). Sacred species and sites are also concentrated in biodiversity-rich nations; in India, for example, there are c. 50 groups of sacred animals (e.g. lizards, snakes, frogs; Krishna, 2014), and more informal sacred sites than formal protected areas (Kala, 2011; Rutte, 2011).

India is home to numerous religious groups, indigenous communities, ethnic groups and regional cultures, each with their own beliefs and taboos (Sinha, 1995; Kanagavel et al., 2014). Religions have long advocated care and passion for nature and the environment, resulting in protection of forest areas, aquatic bodies and various species (Yachkaschi \& Yachkaschi, 2012). In Hinduism many species are considered sacred because of their association with gods and goddesses. Lord Shiva (the destroyer), one of the three main deities of Hinduism, is represented with a spectacled cobra Naja naja around his neck, signifying that he has conquered death, and also representing dormant energy (kundalini). Lord Krishna is one of the 10 incarnations of Lord Vishnu (the protector), another of the three main Hindu deities. In Hindu mythology Lord Krishna is known for his fondness for butter, and one story tells how he hid stolen butter rolled within a leaf of the sacred fig Ficus religiosa. Basil Ocimum sanctum, known locally as tulsi, is also worshipped as a sacred plant, a favourite of Lord Vishnu; the annual ritual Tulsi Vivaha coincides with the start of the Indian marriage season.

Many faunal species are revered as vahanas, or vehicles that carry or transport gods and goddesses. The tiger is associated with the goddess Durga (the invincible), the peacock with Karthikeya (god of war), the owl and elephant with Lakshmi (goddess of wealth, love and prosperity), and crocodiles with the goddess Ganga (the sacred river). 
Similarly in Buddhism, meditating Buddhas (individuals who have attained enlightenment) and some bodhisattvas (those who practise the way of life of a Buddha) have an animal vehicle (Krishna, 2014). The Bodhi tree Ficus religiosa under which the Buddha attained enlightenment is held sacred by Buddhists and is considered to be the tree of life (Mansberger, 1988, cited in Barrow, 2010).

Localized cultural attitudes and practices (e.g. sacred groves, deification of bird, animal or tree species) attributed to indigenous and non-indigenous communities have facilitated effective biodiversity conservation; for example, the Bishnois, a religious sect in the state of Rajasthan, are ecologically conscious and do not cut trees or kill animals (Krishna, 2014). Some Buddhist sects in the north-eastern states and in the western Himalayan regions have evolved community conservation practices, including bans on hunting and fishing, and play an important role in the protection of threatened species, such as the black-necked crane Grus nigricollis (Mazumdar \& Samal, 2012).

The belief in supernatural monitoring (Rossano, 2007) and punishment (Johnson \& Krüger, 2004) deters people from violating norms and breaking social rules, and may have played a vital role in maintaining sacred sites in India (Gadgil \& Vartak, 1974). It is also likely to have contributed to the conservation of freshwater fishes, which have been associated with supernatural beings (Dandekar, 2011; Katwate et al., 2014).

\section{Religion and freshwater fishes in India}

Freshwater fishes have been considered sacred in many parts of India since the Vedic period (1750-500 BC; Nautiyal, 2014). Species of mahseer (Tor spp.), for example, a threatened group of cyprinid fishes (Pinder \& Raghavan, 2013), are mentioned in various religious scriptures as being valued for propitiating the souls of deceased ancestors and relished by forest-dwelling saints (Nautiyal, 2014). This reverence for mahseer continues and the fishes are protected in several stretches of rivers associated with temples (Dandekar, 2011; Fig. 1), where fishing is prohibited and local communities, pilgrims and temple authorities help to monitor and safeguard the fish population.

In Walan Kond (Savitri River) in the northern part of the Western Ghats, local people regard mahseer as the children of the goddess Parvathi (Katwate et al., 2014). On the Tunga River, also in the Western Ghats region, the Sringeri fish sanctuary protects threatened cyprinids of the genera Hypselobarbus, Neolissochilus and Tor. Chippalgudde Matsya Dhama, another sanctuary on the same river, protects, among other fishes, the endemic herbivorous cyprinid Hypselobarbus pulchellus, categorized as Critically Endangered on the IUCN Red List (Rema Devi \& Ali, 2013). The fishes are considered sacred as they are associated with Lord Vishnu, whose first incarnation on Earth was in the form of a fish. In this incarnation Lord Vishnu is believed to have saved the first human on Earth by informing him of the calamitous floods that were to follow. Many tributaries of the River Ganges are considered sacred, and religious sentiments play a positive role in the protection of the Endangered golden mahseer Tor putitora (Jha \& Rayamajhi, 2010) in this region (Dandekar, 2011). Local worship of the fish god is a key driver of conservation at Machchiyal Lake in the state of Himachal Pradesh, where the fishes are fed regularly by local people and tourists. The temple authorities keep the water free of pollution, and prevent exploitation by local people (Plate 1).

The charismatic and threatened mahseer species are probably better protected in such sacred sites (Gadgil et al., 2001; Gupta et al., 2015) than in unprotected openaccess areas, where they are subjected to indiscriminate (often destructive) fishing, and habitat loss as a result of hydroelectric projects and pollution (Pinder \& Raghavan, 2013; Nautiyal, 2014; Gupta et al., 2014a). The mainstays of this protection are the prohibition of fishing in these waters, the availability of food (through artificial feeding), and active monitoring against pollution and other hydrological changes. Community-based educational programmes have improved the water quality in many temple pools by ensuring protection of upstream and downstream reaches (Dandekar, 2011; Gupta, 2013).

\section{Ecological and socio-political issues}

Although freshwater fishes are one of the most threatened vertebrate groups (Leidy \& Moyle, 1997; Carrizo et al., 2013) they are often neglected in conservation efforts, including in countries rich in freshwater biodiversity, such as India. None of the $>150$ threatened freshwater fish species in India (IUCN, 2014) are legally protected or the focus of species-specific conservation plans. The increasing threat to freshwater ecosystems and fish species in India has been the subject of debate not only among scientists but also among stakeholders, including local communities (Gupta et al., 2014c). However, the role of stakeholders in freshwater biodiversity conservation is often overlooked by policy makers (Gupta et al., 2014b) as a result of overt emphasis on centralization and adoption of a technocentric approach to managing ecological entities (Gupta et al., 2014b).

Despite the apparent conservation benefits of sacred sites, several ecological and policy-related concerns have yet to be addressed (Dudley et al., 2009). Providing legal status to sacred sites would help ensure additional protection for these areas but could also undermine the concept of religious values and traditions associated with the sites (Dudley et al., 2009) if local communities were allowed only limited access. The success of legally protected sites is often hindered by poor management and enforcement because of a lack of human resources (Kanagavel et al., 2013) 

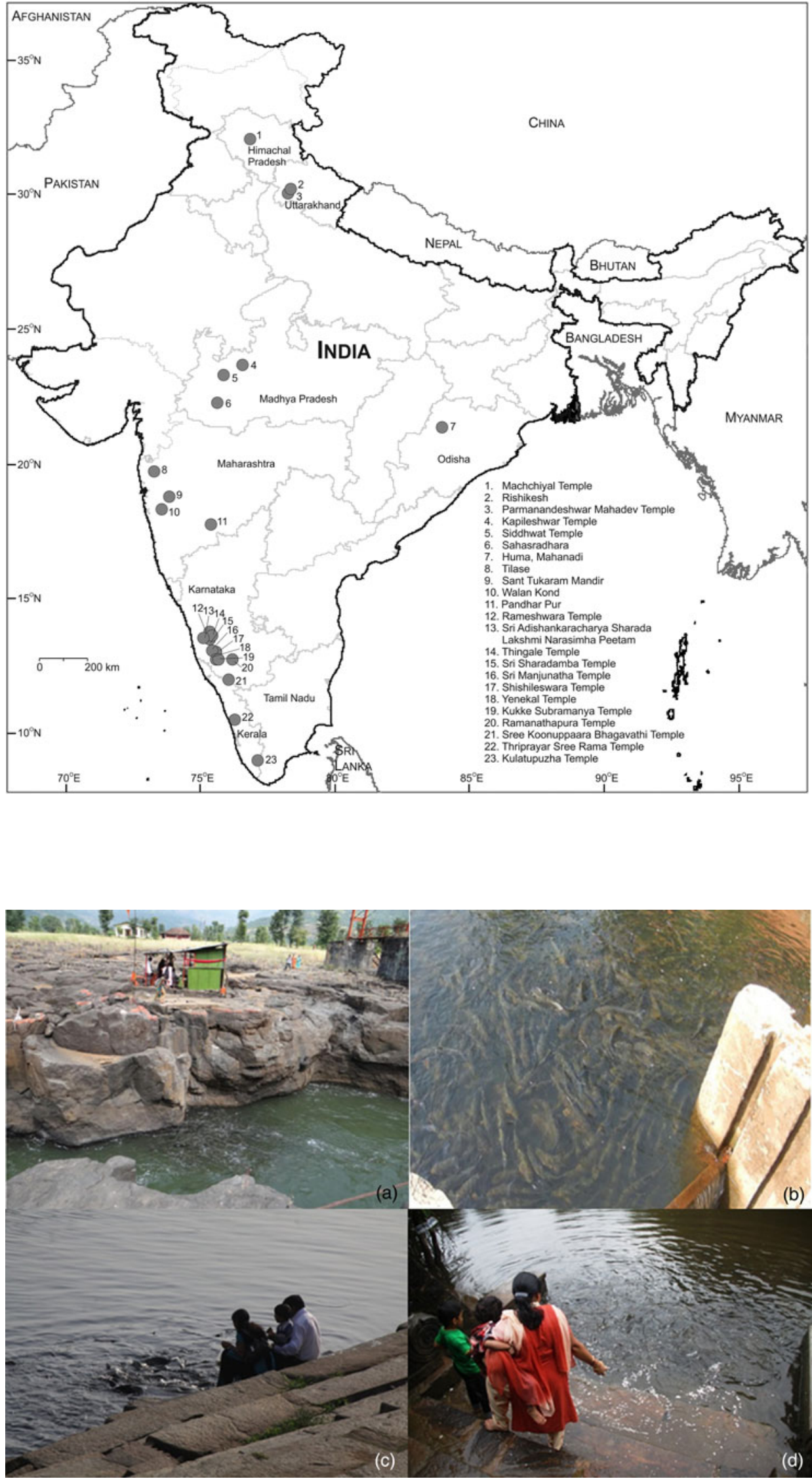

FIG. 1 Locations of important temple fish sanctuaries in India.
Plate 1 Temple fish sanctuaries in (a) Walan Kond (site 10 in Fig. 1), (b) Yenekal Temple (14), (c) Ramanathapura Temple (20) and (d) Shishileswara Temple (17). ( $a$ and b C Parineeta Dandekar; $\mathrm{c}$ and d @ Shrinivas Kadabagere) 
and in some cases the transfer of site ownership to Forest Departments has resulted in conflict with local communities, which has adversely affected site management (Gadgil, 1991; Bhagwat \& Rutte, 2006). To avoid this, the legislative arrangement should empower the primary stakeholders and uphold their rights, and put land-use and management mechanisms in place rather than devolving and transferring management to the Forest Department. The legislation should promote the bio-cultural diversity of individual sites rather than focusing on biodiversity alone, given the interdependence of biodiversity and cultural values at these locations (Verschuuren, 2010). Sacred sites could also benefit from being integrated into a larger, state-level conservation landscape.

The most important ecological challenge related to temple fish sanctuaries is the need to manage their upstream reaches so that the sacred sites are not damaged by stressors that originate in other places. One way to achieve this is through the establishment of safe zones where sustainable and regulated fishing activity is promoted, potentially yielding social and economic benefits for local stakeholders (Gupta et al., 2014b). Another emerging question is whether temple sanctuaries serve as arks (where fish can mature, reproduce and help repopulate adjoining areas) or cages (where they can survive but are unable to reproduce because of unsuitable habitat or other hindrances; Kumar \& Devi, 2013). Whether temple sanctuaries alter the life history traits (e.g. feeding behaviour, reproduction) of fish is therefore a priority for future research. There is also a need to explore non-invasive means of monitoring and stock assessment, such as the use of hydro-acoustics or video cameras.

Many community-conserved fish sanctuaries at Indian temples are threatened by the proliferation of hydropower projects (e.g. Nakur Gaya and Hosmata in Karnataka, and Walan Kond and Tilase in Maharashtra; Dandekar \& Thakkar, 2015). Environmental impact assessments do not even mention the existence of such fish sanctuaries, nor are the communities managing the sanctuaries involved in making or implementing decisions related to dams (Dandekar \& Thakkar, 2015).

The erosion of religious beliefs, an increase in religious heterogeneity, and changing traditions are potential drivers of the increasing threats to sacred sites (Gadgil, 1991; Bhagwat \& Rutte, 2006). In promoting freshwater conservation through temple fish sanctuaries it is essential that linkages between religion, culture and conservation (McKay, 2014) are highlighted in a non-discriminatory manner to avoid causing divisions among people of different religions, which could have an adverse effect on conservation efforts.

The bio-cultural conservation of freshwater fishes should not be limited to temple sanctuaries but expanded to include individuals, communities or organizations interested in facilitating and coordinating such initiatives. However, informal institutions such as temple sanctuaries serve as models for the survival and dissemination of beliefs that support the conservation of nature, habitats and species. These beliefs could be retold as simple stories that emphasize their positive value, and not the religion from which the beliefs originate. However, to achieve long-term conservation benefits it will be necessary to inspire people to put their beliefs into action.

Research suggests that sacred spaces harbour species of scientific importance in significant abundance, and in many cases these are the last remaining relics of the original landscape and species (Dudley et al., 2010). Although not all temple sanctuaries necessarily harbour endemic and threatened freshwater fishes, it is the pro-conservation beliefs in place that are of significance and should be harnessed to promote freshwater fauna and habitats, regardless of the species involved. Conservation organizations could focus attention primarily on those sacred spaces that encompass critical habitats and species, and establish partnerships with faith groups to assist in the fulfilment of conservation goals (McKay, 2014).

\section{The way forward}

Temple sanctuaries continue to exist in India but diminishing dependence on traditional dogmas may mean that religious beliefs and taboos are unlikely to be prioritized in the future (Bhagwat \& Rutte, 2006). This is particularly pertinent in the case of marginalized communities living along river banks, for whom fish is a cheap source of protein, and fisheries a livelihood option. Incentive-driven conservation (Hutton \& Leader-Williams, 2003) in the form of national recognition and provision of financial support for maintaining or improving the water quality at sanctuaries could ensure that such informal protected areas provide much-needed protection for threatened freshwater taxa. There is a need for a greater understanding of the short and long-term socio-economic, environmental and conservation impacts of such sacred sites (Berkes, 2004). With the current dearth of conservation options for freshwater biodiversity (Strayer \& Dudgeon, 2010), whether sacred sites can be supported legislatively and utilized as an additional safeguarding mechanism can be ascertained only through rigorous scientific studies that involve locally relevant stakeholders.

\section{Acknowledgements}

We thank Steven Cooke and three anonymous reviewers for their critical comments and suggestions, Unmesh Katwate for information, and Shrinivas Kadabagere for photographs.

\section{References}

Anthwal, A., Gupta, N., Sharma, A., Anthwal, S. \& Kim, K.H. (2010) Conserving biodiversity through traditional beliefs in sacred groves in Uttarakhand Himalaya, India. Resources, Conservation and Recycling, 54, 962-971. 
BARrow, E.G.C. (2010) Falling between the 'cracks' of conservation and religion: the role of stewardship for sacred trees and groves. In Sacred Natural Sites: Conserving Nature and Culture (eds B. Verschuuren, R. Wild, J.A. McNeely \& G. Oviedo), pp. 42-52. Earthscan, London, UK.

BERKES, F. (2004) Rethinking community-based conservation. Conservation Biology, 18, 621-630.

Bhagwat, S.A., Dudley, N. \& Harrop, S.R. (2011) Religious following in biodiversity hotspots: challenges and opportunities for conservation and development. Conservation Letters, 4, 234-240.

Bhagwat, S.A. \& Palmer, M. (2009) Conservation: the world's religions can help. Nature, 461, 37.

Bhagwat, S.A. \& Rutte, C. (2006) Sacred groves: potential for biodiversity management. Frontiers in Ecology and the Environment, 4, 519-524.

Carrizo, S.F., Smith, K.G. \& Darwall, W.R.T. (2013) Progress towards a global assessment of the status of freshwater fishes (Pisces) for the IUCN Red List: application to conservation programmes in zoos and aquariums. International Zoo Yearbook, 47, 46-64.

Colding, J. \& Folke, C. (1997) The relations among threatened species, their protection, and taboos. Conservation Ecology, 1, 1-12.

DANDEKAR, P. (2011) India's community fish sanctuaries protect wild fish and rivers. World Rivers Review, 26, 1-7.

DANDEKAR, P. \& THAKKAR, H. (2015) River sanctuaries: worshipping endangered fish and rivers. Global Conference on Inland Fisheries, 26-28 January 2015, FAO, Rome, Italy.

Dudley, N., Bhagwat, S., Higgins-Zogib, L., Lassen, B., VersChUUREN, B. \& Wild, R. (2010) Conservation of biodiversity in sacred natural sites in Asia and Africa: a review of the scientific literature. In Sacred Natural Sites: Conserving Nature and Culture (eds B. Verschuuren, R. Wild, J.A. McNeely \& G. Oviedo), pp. 19-32. Earthscan, London, UK.

Dudley, N., Higgins-Zogib, L. \& Mansourian, S. (2009) The links between protected areas, faiths, and sacred natural sites. Conservation Biology, 23, 568-577.

GADGIL, M. (1991) Conserving India's biodiversity: the societal context. Evolutionary Trends in Plants, 5, 3-8.

Gadgil, M., Chandrasekhariah, H.N. \& Bhat, A. (2001) Freshwater fish: out of sight, out of mind. Survey of the Environment 200o, pp. 137-142. The Hindu, Chennai, India.

GADGIL, M. \& VARTAK, V.D. (1974) Sacred groves of India: a plea for continued conservation. Journal of the Bombay Natural History Society, 72, 313-320.

Gupta, N. (2013) Reflections on a successful community conservation programme in Haryana, India. Journal of Development Management, 1, 117-122.

Gupta, N., Nautiyal, P., Borgohain, A., Sivakumar, K., Mathur, V.B. \& ChADwick, M.A. (2014a) Catch-and-release angling as a management tool for mahseer conservation in India. Oryx. Http:// dx.doi.org/10.1017/So030605314000787 [accessed 30 July 2015].

Gupta, N., Raghavan, R., Sivakumar, K. \& Mathur, V.B. (2014b) Freshwater fish safe zones: a prospective conservation strategy for river ecosystems in India. Current Science, 107, 949-950.

Gupta, N., Sivakumar, K., Mathur, V.B. \& Chadwick, M.A. (2014c) The 'tiger of Indian rivers': stakeholders' perspectives on the golden mahseer as a flagship fish species. Area, 46, 389-397.

Gupta, N., Sivakumar, K., Mathur, V.B. \& Chadwick, M.A. (2015) Terrestrial protected areas and managed reaches conserve threatened freshwater fish in Uttarakhand, India. PARKS, 21, 89-101.

Hutton, J.M. \& Leader-Williams, N. (2003) Sustainable use and incentive-driven conservation: realigning human and conservation interests. Oryx, 37, 215-226.

IUCN (2014) The IUCN Red List of Threatened Species. 2014.2. Http:// www.iucnredlist.org [accessed 15 September 2014].
JHA, B.R. \& Rayamajhi, A. (2010) Tor putitora. In The IUCN Red List of Threatened Species v. 2015.2. Http://www.iucnredlist.org [accessed 31 July 2015].

Johnson, D.D.P. \& KRUGER, O. (2004) The good of wrath: supernatural punishment and the evolution of cooperation. Political Theology, 5, 159-176.

KALA, C.P. (2011) Traditional ecological knowledge, sacred groves and conservation of biodiversity in the Pachmarhi Biosphere Reserve of India. Journal of Environmental Protection, 2, 967-973.

Kanagavel, A., Pandya, R., Prithvi, A. \& Raghavan, R. (2013) Multi-stakeholder perceptions of efficiency in biodiversity conservation at limited access forests of the southern Western Ghats, India. Journal of Threatened Taxa, 5, 4529-4536.

Kanagavel, A., Raghavan, R. \& Veríssimo, D. (2014) Beyond the "general public": implications of audience characteristics for promoting species conservation in the Western Ghats Hotspot, India. Ambio, 43, 138-148.

Katwate, C., Pawar, R., Shinde, V., Apte, D. \& Katwate, U. (2014) How long will social beliefs protect the pride of River Savitri? MIN, 2, 21-24.

Krishna, N. (2014) Sacred Animals of India. Penguin India, Gurgaon, India.

Kumar, R. \& DeVi, K.R. (2013) Conservation of freshwater habitats and fishes in the Western Ghats of India. International Zoo Yearbook, 47, 71-80.

Leidy, R.A. \& Moyle, P.B. (1997) Conservation status of the world's fish fauna: an overview. In Conservation Biology for the Coming Decade (eds P.L. Fiedler \& P.M. Kareiva), pp. 187-227. Chapman \& Hall, New York, USA.

MANSBERGer, J.R. (1988) In search of the tree spirit: evolution of the sacred tree Ficus religiosa. In Changing Tropical Forests: Historical Perspectives on Today's Challenges in Asia, Australasia and Oceania (eds J. Dargavel, K. Dixon \& N. Semple). Centre for Resource and Environmental Studies, Australian National University, Canberra, Australia.

MaZumdar, K. \& SAMAL, P.K. (2012) Conservation, management and hunting of faunal resources among Monpas and Sherdukpens in Arunachal Pradesh, Eastern Himalaya. In Cultural Landscapes: The Basis for Linking Biodiversity Conservation with the Sustainable Development (eds P.S. Ramakrishnan, K.G. Saxena, K.S. Rao \& G. Sharma), pp. 91-103. UNESCO, New Delhi, India.

MCKAY, J.E. (2014) Practise what you preach: a faith-based approach to conservation in Indonesia. Oryx, 48, 23-29.

Mikusiński, G., Possingham, H.P. \& Blicharska, M. (2014) Biodiversity priority areas and religions-a global analysis of spatial overlap. Oryx, 48, 17-22.

Nautiy al, P. (2014) Review of the art and science of Indian mahseer (game fish) from nineteenth to twentieth century: road to extinction or conservation? Proceedings of the National Academy of Sciences, India, 84, 215-236.

Norenzayan, A. \& Shariff, A.F. (2008) The origin and evolution of religious prosociality. Science, 322, 58-62.

Pinder, A.C. \& Raghavan, R. (2013) Conserving the endangered mahseers (Tor spp.) of India: the positive role of recreational fisheries. Current Science, 104, 1472-1475.

Rema Devi, K.R. \& Ali, A. (2013) Hypselobarbus pulchellus. In The IUCN Red List of Threatened Species v. 2015.2. Http://www. iucnredlist.org [accessed 31 July 2015].

Rossano, M.J. (2007) Supernaturalizing social life: religion and the evolution of human cooperation. Human Nature, $18,272-294$.

Rutte, C. (2011) The sacred commons: conflicts and solutions of resource management in sacred natural sites. Biological Conservation, 144, 2387-2394. 
SinHA, R.K. (1995) Biodiversity conservation through faith and tradition in India: some case studies. International Journal of Sustainable Development \& World Ecology, 2, 278-284.

Strayer, D.L. \& Dudgeon, D. (2010) Freshwater biodiversity conservation: recent progress and future challenges. Journal of the North American Benthological Society, 29, 344-358.

Verschuuren, B. (2010) Arguments for developing biocultural conservation approaches for sacred natural sites. In Sacred Natural Sites: Conserving Nature and Culture (eds B. Verschuuren, R. Wild, J.A. McNeely \& G. Oviedo), pp. 62-72. Earthscan, London, UK.

WW F (2014) Living Planet Report 2014: Species and Spaces, People and Places (eds R. McLellan, L. Iyengar, B. Jeffries \& N. Oerlemans). WWF, Gland, Switzerland.

YACHKASCHI, A. \& YACHKASCHI, S. (2012) Nature conservation and religion: an excursion into the Zoroastrian religion and its historical benefits for the protection of forests, animals and natural resources. Forest Policy and Economics, 20, 107-111.

\section{Biographical sketches}

Nishikant Gupta is interested in river and fish conservation in India. ARUN KANAGAVEL is interested in social dimensions of nature conservation and their role in influencing pro-conservation behaviour. Parineeta Dandekar works for a civil society organization on issues related to water governance, infrastructure projects and their impacts on people and ecosystems. NeELESH DAHANUKAR is interested in ecology and evolution, with an emphasis on statistical analysis, as well as taxonomy, distribution patterns, molecular phylogeny and conservation of freshwater fish. KUPPUSAMY SiVAKUMAR's interests include fish and avian ecology, island ecology, marine biology, invasive species and Antarctic wildlife. VINOD MATHUR's interests include biodiversity conservation, environmental and strategic impact assessment, biodiversity informatics and natural heritage conservation. RAJEEV RAGHAVAN's research focuses on generating information to support conservation decision making in tropical freshwater ecosystems, with a special focus on the Western Ghats-Sri Lanka biodiversity hotspot. 